\title{
TRANSLATION OF COLOUR TERMS: AN EMPIRICAL APPROACH TOWARD WORD-TRANSLATION FROM ENGLISH INTO ESTONIAN
}

\author{
Mari Uusküla \\ Tallinn University
}

\begin{abstract}
Translation of colour terms hovers somewhere between cognitive linguistics and translation studies and has therefore remained relatively understudied as a topic, despite the popularity of cross-linguistic colour term studies in the languages of the world. Although colour terms form a relatively small and restricted semantic domain, translating a colour term into another language can cause a massive headache to anyone who has ever tried to seek an appropriate equivalent for it in another language. The article describes how a group of translators and non-translators translated single, mainly simplex secondary colour terms from English into Estonian. Four main translation strategies can be discerned: literal translation, abstraction change or hyponymy, information change or omission and descriptive translation techniques. In addition, the study shows that translation experience and translation education is an advantage even if one translates small units of texts.
\end{abstract}

Keywords: semantics, translation, cognitive linguistics, culture-specific words, objectderived colour terms, cultural keywords

DOI: https://doi.org/10.12697/jeful.2019.10.2.05

\section{Introduction}

While colour terms in linguistics and psycholinguistics form a wellestablished area of research, translation of colour terms has received little attention, and therefore calls for further development. And this is no wonder, since the term translation is usually applied in reference to sentences, phrases or even larger units of text written in various modalities or genres. If one is translating, it is essential to translate ideas instead of words so that the meaning may be transferred into another language even with omissions in texts. However, translation of words is sometimes inevitable, and can cause at least as much uncertainty as translating entire sentences or whole ideas into another language. 
In translating colour terms from one language into another it is important to understand the intersection between linguistics, translation, culture and colour terms. The rapport between translation studies and linguistics has been a "love-hate" one due to various reasons (Rojo and Ibarretxe-Antuaño 2013: 3). Some linguists and translators find it easier to leave colour words in a text untranslated which could be considered a well-established and suitable technique, rather than seeking an appropriate translation equivalent which might still be misleading despite the best endeavours of the translator, or might carry different connotations in the target language and therefore culture. Colour terms are by no means the only difficult translation units, but belong at least to a group of hard-to-translate words. The current article uses the concepts of cognitive linguistics and colour studies and tries to domesticate the results partially into the framework of translation studies to explain the translation strategies or techniques of colour terms. Translation strategy usually refers to larger units of text, but can also be used as a synonym to techniques. In the present article strategy and technique are used as synonyms.

The impetus behind the present article is my own experience as a field linguist who has carried out controlled psycholinguistic field experiments on a number of European languages (see Uusküla and Bimler 2016). Namely, I often encountered untranslatable colour words which can even be interpreted as cultural keywords (Levisen and Waters 2017). One of the well-established examples is the famous case of Hungarian reds piros and vörös (Uusküla 2011). It is difficult to find an appropriate translation equivalent to the Hungarian vörös, because red does not carry all the specific connotations and semantic associations related to the concept. If one translates Hungarian vörös into English red the translation could be considered only partly accurate, as English red does not cover all particular collocations and connotations as vörös has. Many Italian words for blue (Bimler and Uusküla 2017, Uusküla 2014) attested and confirmed by various researchers (Paggetti et al. 2016, Paramei et al. 2018, Sandford 2011) form an equally difficult case as they do not correspond to English blue. If someone has ever tried translating the Italian blu, azzurro or celeste into any other language, they know that every attempt seems to be a failure.

The second point of departure towards this piece of writing was the knowledge I gained when researching published Italian-Estonian 
dictionaries (Tavast and Uusküla 2015), a phenomenon also discussed by Barratt and Kontra (1996). Our goal was to shed light on the dictionary entries of Italian blu, azzurro and celeste which resulted in finding a glaring discrepancy between what was presented in most Italian-Estonian dictionaries and the actual semantic meaning and popular usage of blu, azzurro and celeste for the native speakers of Italian (Uusküla 2014). Dictionary entries gave contradictory, vague and sometimes even false information about the meaning of these colour terms. This might be due to the number of words present in ItalianEstonian dictionaries - these dictionaries contain a rather limited number of words - though there are various other reasons.

Little specific literature can be found on the translation of colour terms, partly because translation scholars are obviously more interested in texts rather than in the translation of single words, and certainly not the translation of such a small and fairly closed semantic domain as colour terms. The importance of the translation of colour terms can be discussed usually by someone, who has made attempts to translate colour terms from one language into another. J. C. Catford (1965: 44) refers to "transference", which should be used in cases where the source language colour system, or the system of any other lexical item, does not have a one-to-one correspondence in a target language. His example comes from Navajo, which probably has only one colour term as a substitute for at least three English colour terms - green, blue and purple. Apart from this example, translation of colour terms has garnered much more interest in linguistics than in translation studies (Bazzanella et al. 2016, Chatti 2015, Li 2011). Gill Philip (2011: 170), in particular, raises the question of translation equivalents and describes several techniques for translating colour terms in texts. Carole Biggam (2012: 137-143) underlines that an interdisciplinary approach between linguistics, translation studies and other relevant research areas is essential.

The focus of this article is on the actual translation of colour terms in tasks where participants were requested to do their best to translate mainly simplex secondary colour terms (Casson 1994). We observe the techniques and strategies used by participants if asked to translate such object-derived colour terms as the English lemon, salmon, coral or others into a language which uses different compound derivational patterns such as Estonian. The purpose is also to study different 
language- or culture-specific colour terms which do not have a one-toone equivalent in any language other than the original one. In addition, we observe whether professional translators and non-trained individuals differ in how they translate colour terms.

\section{Methods and procedures}

This article draws on data gathered in the year 2015. The sample consisted of volunteer participants who were 'blind' to the subject until the immediate beginning of the task in a sense that they did not know that they would be asked to translate colour terms. 20 participants took part in the study. Weller and Romney (1988) consider this sample size enough to draw conclusions. The task was completed on A4 paper. Participants are additionally described in Table 1.

\subsection{Translation tasks}

The first part of the task was designed in collaboration and carried out by Liina Kivimets in 2015 (Kivimets 2015). 20 participants (5 male) were requested to translate context-free colour terms into their native language Estonian. In the second part of the task the same participants were requested to translate some sentences which contained the same or different colour terms as in the context-free part of the experiment. They performed a colour-naming task after the two translation tasks of word-translation and sentence-translation. The sentence translation task and the colour naming task will not be analysed in this article.

In the word-translation task, 17 words derived from object names were selected from Seija Kerttula's monograph on English colour terms (2002) and presented to the participants on an A4 sheet of paper with a request to translate all the words into Estonian: rose, ivory, lemon, coral, lilac, chocolate, pink, cream, lavender, turquoise, salmon, plum, olive, violet, peach, mauve and amber. Object-derived colour terms are mostly non-basic colour terms, although some of them might be basic as well, e.g. pink. Casson (1994: 7) calls non-basic colour terms that are developed metonymically by following the principle "Entity stays for the entity's colour" neatly simplex secondary colour terms. Of the colour terms used in the present study at least chocolate, cream, ivory, lemon, lilac, rose and salmon could be considered semantically transparent, but 
not regarded as figurative expressions or elaborations (Casson 1994: 8). However, amber, lavender and mauve are opaque secondary hue terms, i.e. the meaning of these words is synchronically unanalysable (Casson 1994: 8). These are all conventional colour terms for the speakers of a present-day English and are therefore understandable to native speakers. The only colour term that most English speakers think of as a colour rather than an object, is probably pink. Of 17 selected colour terms used in the present study, only violet is a Middle English colour term, whereas amber, ivory, olive and rose are considered to date back to Early Modern English; all other colour terms emerged in the Modern English period starting from ca 1700 (Casson 1994: 10-11).

The instructions to the participants were given in Estonian and were the following: "On a piece of paper you find a list of English colour terms. Please translate all of them into Estonian. Please offer the best translation that you can think of. Do not worry, there are no right or wrong answers. Just translate what you think is accurate. If you do not know how you would translate a colour term, you can skip the term and move on to the next one. Please translate as many colour terms as possible."

\subsection{Participants}

All participants were volunteers; they did not receive credit points or a fee for their participation. All participants were native speakers of Estonian with a range of social, educational and linguistic backgrounds. All participants self-reported to have C1 English level according to the Common European Framework of Reference for Languages (CEFR). All participants were tested individually.

The sample consisted of eight translators (mean age 32.6 years) and 12 people with no translation experience (mean age 28.4 years) whom I hereby call non-translators (as presented in Table 1).

Table 1. Participants in the English-Estonian translation task

\begin{tabular}{lr}
\hline No. of participants & 20 (5 male) \\
\hline Age range & $19-58$ (mean age 30.9) \\
Non-translators & 12 (age 19-58, mean age 32.6, 4 male) \\
Translators & 8 (age 25-37, mean age 28.4, 1 male) \\
\hline
\end{tabular}


In the non-translator group there were IT specialists, teachers, clerks, bartenders, university students, customer service representatives, etc. All experienced translators had a university degree in either translation or interpretation. They had translated novels or technical, legal or economic texts, or were specialists in audio-visual translation or localisation and their experience varied from 8 to 25 years. Experienced translators were expected to use different translation strategies than nonexperienced individuals.

\section{Results}

Several implications can be drawn from analysis of the data gathered. First, some examples of the word-translation task will be provided. Finally, some common translation strategies and techniques that emerged during the translation task will be introduced. Mixed methods are used for the analysis. The foremost goal is to introduce a classification of translation strategies which could be used as potential aids of translation of colour terms in the future.

\subsection{Translation of colour terms in a context-free setting: English-Estonian task}

Seventeen English colour words were translated into Estonian using 112 different equivalents in Estonian, of which 93 were unique. The most frequently offered Estonian equivalents for all English colour terms are available in Appendix 1.

Overall, on 30 occasions ( $8.8 \%$ of all occasions) participants left the English words untranslated. Of these occasions, only one translator and one interpreter left altogether four words untranslated. A translator left violet and mauve untranslated and an interpreter did not translate two words: amber and lavender. This makes up only $1 \%$ of words presented in the task, whereas $7 \%$ of words were left untranslated by the nontranslator group.

The most used translation technique was literal translation, used in 226 occasions out of a possible maximum number 340 (if all 20 participants had translated all 17 colour words literally), e.g. an English basic colour term pink was translated using the Estonian basic colour 
term roosa. I hereby use the term 'literal translation' when basic colour term was translated with an equal basic colour term or when an English colour term was translated into Estonian grammatically correctly, e.g. chocolate was translated into Estonian as šokolaadipruun, literally 'chocolate brown'. Literal translation was far more frequent (approximately five times more) than the second most applied technique of abstraction or hyponymy (used 46 times from a possible maximum of 340), e.g. turquoise was translated into Estonian as sinine 'blue', salmon as roosa 'pink', peach as oranž 'orange' or olive as rohekas 'greenish'. Some obvious mistranslation occurred with colour terms which were unfamiliar to the participants, e.g. coral was translated into Estonian once as sinine 'blue', once as helesinine 'light blue' and once as türkiissinine 'turquoise blue'; mauve was translated as pruun 'brown'. Other examples of used translation strategies are discussed in Subsection 3.2.

Colour terms that were translated with a high consensus among participants were lemon (which 14 participants translated as sidrunikollane 'lemon yellow'), chocolate (which 13 participants translated as šokolaadipruun 'chocolate brown') and salmon (translated by 12 participants as lõheroosa literally 'salmon pink') and turquoise (12 participants translated the colour word as türkiissinine 'turquoise blue', followed by 5 who translated the given colour terms as türkiis as shown in Table 2). Seven experienced translators translated turquoise into Estonian as türkiissinine, using a compound, whereas five participants opted for object-derived adjective türkiis which sounds foreign in Estonian.

Table 2. Translation of English turquoise into Estonian

\begin{tabular}{llc}
\hline Estonian equivalent & English gloss & $\mathrm{N}=20$ \\
\hline türkiissinine & turquoise blue & 12 \\
türkiis & turquoise & 5 \\
sinakasroheline & bluish green & 1 \\
rohekassinine & greenish blue & 1 \\
sinine? & blue? & 1 \\
\hline
\end{tabular}

Both pink and rose were translated as roosa 'pink' which refers to the fact that foreign English speakers do not know that these colour terms are derived from object names. Pink as a noun refers to a Dianthus of 
the family Caryophyllaceae. Cambridge Dictionary defines pink plant as "a small garden plant with sweet-smelling pink, white, or red flowers and narrow, grey-green leaves, or one of its flowers"1. Two participants omitted translating rose into Estonian. Experienced translators tended to remain true to the original concept of rose. Their translations are in bold in Table 3 .

Table 3. Translation of English rose into Estonian

\begin{tabular}{llc}
\hline Estonian equivalent & English gloss & $\mathrm{N}=20$ \\
\hline roosa & pink & 9 \\
roosipunane & rose red & 3 \\
- & - & 2 \\
roosikarva & rose coloured & 1 \\
roosiöitevärvi & colour of a rose (petal) & 1 \\
punane & red & 1 \\
verevpunane & scarlet red & 1 \\
heleroosa & light pink & 1 \\
roosakas & pinkish & 1 \\
\hline
\end{tabular}

English violet was translated into Estonian both as the non-basic colour term violetne and a basic colour term lilla 'purple'. The use of translation of these two words shows that the form was preserved rather than the actual meaning. As the Estonian violetne is a borrowing from Swedish and the concept is not domesticated, it differs from English violet both in meaning and in colour. Of the experienced translators, seven translated the colour term into Estonian as violetne, while only one preferred to use lilla.

Table 4. Translation of English violet into Estonian

\begin{tabular}{llc}
\hline Estonian equivalent & English gloss & $\mathrm{N}=20$ \\
\hline violetne & purplish & 12 \\
lilla & purple & 7 \\
sinakaslilla & bluish purple & 1 \\
\hline
\end{tabular}

1 https://dictionary.cambridge.org/dictionary/english/pink. 
The most difficult colour word to translate was mauve: 11 participants omitted translating this colour term as they were either not familiar with it or explained to the researcher that they could not find an appropriate equivalent in English that would carry the same meaning as in Estonian. Two participants (one of them an experienced translator) translated mauve as kahvatulilla 'pale purple' which could probably be considered as the best equivalent to mauve in Estonian.

After the participants had completed the translation tasks and a colour-naming task in Estonian in which results will be reported elsewhere, they were also asked to reflect on what was difficult. Participants felt that it was difficult to provide excellent translations if one wanted to take into account all colour nuances. One participant added in the free commentary after the task that there seem to be fewer colour words in Estonian than in English, as one always had to use a compound word in Estonian, while in English you could describe a specific colour with a simple word, e.g. maroon.

\subsection{Common translation strategies of colour terms}

Certain translation strategies were often used by the participants rather than others for source-target language pairs. Literal translation is a fairly applicable technique to translation of colour terms. This applies to all instances where translations followed the source language patterns, and to source language basic colour terms which were translated with an equal basic colour term in the target language if available, e.g. pink was translated as roosa, lemon was translated as sidrunikollane.

Abstraction change or hyponymy was the second frequent technique. This was applied to language-specific and culture-specific colour terms, which were sometimes preserved in the pattern Venuti calls foreignization (1995), while others were substituted or brought into familiar form and context or domesticated (Venuti 1995: 20). I would consider a preservation of roosiõievärvi 'colour of a rose petal' as an attempt to transfer the concept of rose into Estonian.

The third frequent technique used by the participants was information change or even omission. Sometimes translation was entirely omitted or, if applied to sentences, it was substituted by other information (e.g. the original text had a colour term, which was not translated into the target language, especially if two occurring words in the sentences could be considered near synonyms). 
The fourth most common technique used by the participants was descriptive translation - this meant adding a commentary or a footnote to translations, explaining the colour word or concept in more detail to the researcher. All these techniques can probably be used for the translation of colour terms.

\section{Discussion}

Basic colour terms in one language often match the basic colour term system of another language (Berlin and Kay 1969) and should therefore be fairly easy and straightforward to translate between languages, if the basic colour terms coincide between source and target languages. In translation tasks basic colour terms posed the easiest challenge to the participants to meet, the participants knew the most frequently used translation, which shows their familiarity to English language. In contrast, participants left some non-basic colour terms untranslated, especially the ones that were not so common. We observe this in translation of the concept-based or culture-specific colour terms in the English-Estonian translation task. The more culture-specific the concept, the smaller the scale of consensus that could be found among the participants, as was the case with mauve. The most difficult items in the English-Estonian translation tasks were the colour terms lavender, which only four people translated as helelilla 'light purple' while the rest gave other equivalents, and amber, which only five translated as merevaigukollane 'amber yellow', whereas there was $100 \%$ consensus among translators in offering translations for blue and green which were both translated with the coequal BCTs, sinine and roheline (Kivimets 2015). An observable pattern occurred whereby the more basic the colour term, the higher the consensus rate among the participants. Andrew Chesterman $(2000,2004)$ uses the unique items hypothesis to explain such transpositions between languages. In his terminology the case of sidrunikollane turning into lemon yellow would be called an over-represented item, whereas under-represented items are cases where lemon is translated into Estonian as sidrun 'lemon', which refers primarily to the fruit of a lemon tree.

Different from Estonian, English uses zero derivation to derive object-based colour terms as adjectives from nouns. Therefore, peach 
can be both an object (a fruit) used grammatically as a noun, and could be used as a specific colour term, peach (colour) as an adjective, a so called object-derived colour name or term. Estonian, on the contrary, has to add a word 'colour(ed)' to a stem to derive a colour word (Oja 2001), or specify the colour category, such as lemon yellow or lime green. Whereas in English lemon, lime, lavender and other colour terms are used as grammatical, in Estonian sidrun, laim and lavendel need a colour adjective to form correct colour terms sidrunikollane 'lemon yellow', laimiroheline 'lime green', lavendlililla literally 'lavender purple'. In Estonian, sidrun 'lemon' can only be a noun, the fruit of a lemon tree. In order to derive an adjective which refers to colour, either a basic colour term which specifies the category or a word meaning 'colour(ed)' needs to be added to a noun describing an object. This means that three possibilities are grammatical and sensible in Estonian: sidrunikollane 'lemon-yellow', sidrunivärvi and sidrunikarva both 'lemon-colour(ed)'. Estonian native speakers have to domesticate English colour terms into their grammatical constructions. This sometimes results in such translations where peach in English was translated into Estonian as peach yellow or peach pink (see Appendix 1).

It is important to mention that the translator's profession in Estonia is more popular amongst women than amongst men. At Tallinn University, in 2015, only one of 22 admitted students for translation studies was male and this imbalance is quite common in recent years. Therefore, the sample is unbalanced and no conclusion on male or female translators or even non-translators will be made on gender basis. Experienced translators and participants with translation training often used different techniques in the translation tasks as brought out in the numerous examples (see 3.1 and 3.2). They made fewer errors with translation of non-basic colour terms, omitted the translation of fewer colour terms, and even if they hesitated, tried to offer the best equivalent in Estonian. Translators were usually able to translate faster, although the timing was not tracked, but only observed by the researcher. However, this will be taken into account in further studies as it might be worthwhile to track the time of translation. The fact that translators were usually faster in handing their translations to the researcher indicates the importance and the role of translation training. Overall, experienced translators had that something extra which the other participants did not have - this is partly also due to the larger vocabulary at their disposal. 


\title{
5. Conclusion
}

Colour terms are relatively small units from a rather closed semantic field and translating them should be easy and straightforward, but when 20 participants were asked to translate colour terms from English into Estonian we saw that colour terms caused equally as much confusion as any other words or types of text. As most translation strategies are meant to explain how larger items of text are translated, no translation techniques were available exclusively for colour terms. The most common techniques and strategies used for translating colour terms were literal translation, hyponymy, omission or change of information and using additional information such as comments and footnotes. The role of context should never be underestimated in translation. Although the sentence translation task will be discussed elsewhere, it was obvious that the context helped the participants to grasp the meaning of single colour words, even if these were unfamiliar to them (for comparison see Kalda and Uusküla 2019). Experienced translators seem to offer far more accurate and more creative translation equivalents, but more data should be collected in order to make further generalizations.

\section{Acknowledgements}

The contributions of Liina Kivimets who collected the data on the English-Estonian and to all our 20 subjects for their participation are highly acknowledged. Without our volunteers this study would not have been possible. I am indebted to Domicelè Jonauskaitè for her comments on an earlier version of this paper.

\author{
Addresses \\ Mari Uusküla \\ School of Humanities \\ Tallinn University \\ Narva mnt 29 \\ 10120 Tallinn \\ Estonia \\ E-mail:mari.uuskula@tlu.ee \\ Tel.: +3726409385
}




\section{References}

Barratt, Leslie B. and Miklós Kontra (1996) "Matching Hungarian and English color terms". International Journal of Lexicography 9, 2, 102-117. https://doi.org/10.1093/ij1/9.2.102

Bazzanella, Carla, Irene Ronga, and Erling Strudsholm (2016) "Colour words in Danish and Italian idioms". In Geda Paulsen, Mari Uusküla and Jonathan Brindle, eds. Color language and color categorization, 356-387. Newcastle upon Tyne: Cambridge Scholars Publishing.

Berlin, Brent and Paul Kay (1969/1999) Basic color terms: their universality and evolution. Berkeley and Los Angeles: University of California Press.

Biggam, Carole (2012) The semantics of colour: a historical approach. New York: Cambridge University Press.

Bimler, David and Mari Uusküla (2017) "A similarity based cross-linguistic comparison of basicness and demarcation of 'blue' terms". Color Research and Application 42, 362-377. https://doi.org/10.1002/col.22076

Casson, Ronald W. (1994) "Russett, rose, and raspberry: the development of English secondary color terms". Journal of Linguistic Anthropology 4, 1, 5-22. https://doi.org/10.1525/jlin.1994.4.1.5

Catford, J. C. (1965) A linguistic theory of translation: an essay in applied linguistics. Oxford: Oxford University Press.

Chatti, Sami (2016) "Translating colour metaphors: a cognitive perspective". In Mustapha Taibi, ed. New insights into Arabic translation and interpreting, 161-176. Bristol: Multilingual Matters. https://doi.org/10.21832/9781783095254-009

Chesterman, Andrew (2000) Memes of translation: the spread of ideas in translation theory. Amsterdam and Philadelphia: John Benjamins.

Chesterman, Andrew (2004) "What is a unique item?". In Yves Gambier, Miriam Shlesinger and Radegundis Stolze, eds. Doubts and directions in translation studies, 3-13. Amsterdam and Philadelphia: John Benjamins.

Kalda, Anu and Mari Uusküla (2019) "The role of context in translating colour metaphors: an experiment on English into Estonian translation". Open Linguistics 5, 1, 690-705.

Kerttula, Seija (2002) English colour terms: etymology, chronology, and relative basicness. Helsinki: Société Néophilologique.

Kivimets, Liina (2015) Inglise värvinimede tõlkimisest eesti keelde. Masters' Thesis at Tallinn University.

Levisen, Carsten and Sophia Waters (2017) Cultural keywords in discourse. John Benjamins: Amsterdam.

Li, Zhu (2011) "A study on cognitive models in colour term translation between English and Chinese". International Forum of Teaching and Studies 7, 1, 49-57.

Oja, Vilja (2001) Linguistic studies of Estonian colour terminology. Tartu: Tartu University Press.

Paggetti, Giulia, Gloria Menegaz, and Galina V. Paramei (2016). "Color naming in Italian language". Color Research and Application 41, 402-415.

https://doi.org/10.1002/col.21953 
Paramei, Galina, Mauro D’Orsi, and Gloria Menegaz (2018) "Diatopic variation in referential meaning of the "Italian blues"'. In Lindsay W. MacDonald, Carole P. Biggam and Galina V. Paramei, eds. Progress in colour studies: cognition, language and beyond, 83-106. Amsterdam and Philadephia: John Benjamins. https://doi.org/10.1075/z.217.05par

Philip, Gill (2011) Colouring meaning: collocation and connotation in figurative language. Amsterdam and Philadephia: John Benjamins.

Rojo, Ana and Iraide Ibarretxe-Antuaño (2013) "Cognitive linguitics and translation studies: past, present and future”. In Ana Rojo and Iraide Ibarretxe-Antuaño, eds. Cognitive linguistics and translation: advances in some theoretical models and applications, 3-30. Berlin and Boston: Mouton de Gruyter. https://doi.org/10.1515/9783110302943

Sandford, Jodi (2011) "Blu, azzurro, celeste - what color is blue for Italian speakers compared to English speakers?". In Maurizio Rossi, ed. Colour and colorimetry: multidisciplinary contributions. Vol. VII B, 281-288. Rimini: Maggioli Editore.

Tavast, Arvi and Mari Uusküla (2015) "How blue is azzurro? Representing probabilistic equivalency of colour terms in a dictionary". Cultura e Scienza del Colore-Color Culture and Science 4, 43-48.

Uusküla, Mari (2011) "Terms for red in Central Europe: an areal phenomenon in Hungarian and Czech". In Carole P. Biggam, Carole A. Hough, Christian J. Kay and David R. Simmons. New Directions in Colour Studies, 147-156. Amsterdam and Philadelphia: John Benjamins. https://doi.org/10.1075/z.167.17uus

Uusküla, Mari (2014) "Linguistic categorization of blue in standard Italian”. In Wendy Anderson, Carole P. Biggam, Carole A. Hough, and Christian Kay, eds. Colour studies: a broad spectrum, 67-78. Amsterdam and Philadelphia: John Benjamins. https://doi.org/10.1075/z.191.04uus

Uusküla, Mari and David Bimler (2016) "From linguistic data to semantic maps: crosslinguistic commonalities in cognitive representation of colour". Folklore 64, 57-90. https://doi.org/10.7592/FEJF2016.64.colour

Venuti, Laurence (1995) The translator's invisibility: a history of translation. 2nd ed. London and New York: Routledge.

Weller, Susan. C. and A. Kimball Romney (1988) Systematic data collection. London and New Delhi: Sage Publication. 


\section{Appendix 1}

English colour terms in alphabetic order and their translations in Estonian. The fourth column represents translation frequencies - how many participants translated English colour term using that particular Estonian word. En dashes express omissions. Only common Estonian equivalents are brought out. All equivalents provided only once are considered as random and not presented in the table.

\begin{tabular}{|c|c|c|c|}
\hline $\begin{array}{l}\text { English colour } \\
\text { term }\end{array}$ & $\begin{array}{l}\text { Translation in } \\
\text { Estonian }\end{array}$ & English gloss & $\begin{array}{c}\text { Translation } \\
\text { frequency }\end{array}$ \\
\hline \multirow[t]{3}{*}{ amber } & merevaigukollane & amber yellow & 6 \\
\hline & - & - & 5 \\
\hline & merevaigukarva & amber colour(ed) & 2 \\
\hline \multirow[t]{4}{*}{ chocolate } & šokolaadipruun & chocolate brown & 13 \\
\hline & pruun & brown & 2 \\
\hline & šokolaadikarva & chocolate colour(ed) & 2 \\
\hline & tumepruun & dark brown & 2 \\
\hline \multirow[t]{3}{*}{ coral } & korallpunane & coral red & 6 \\
\hline & korall & coral & 4 \\
\hline & korallroosa & coral pink & 2 \\
\hline \multirow[t]{3}{*}{ cream } & kreemikas & creamy & 6 \\
\hline & kreemjas & creamy & 6 \\
\hline & beež & beige & 2 \\
\hline \multirow[t]{3}{*}{ ivory } & elevandiluukarva & ivory colour(ed) & 6 \\
\hline & elevandiluuvalge & ivory white & 3 \\
\hline & - & - & 3 \\
\hline \multirow[t]{4}{*}{ lavender } & lavendlililla & lavender purple & 7 \\
\hline & helelilla & light purple & 4 \\
\hline & lavendlikarva & lavender colour(ed) & 2 \\
\hline & - & - & 2 \\
\hline \multirow[t]{2}{*}{ lemon } & sidrunikollane & lemon yellow & 14 \\
\hline & sidrunkollane & lemon yellow & 2 \\
\hline \multirow[t]{4}{*}{ lilac } & lilla & purple & 9 \\
\hline & sirelililla & lilac purple & 7 \\
\hline & tumelilla & dark purple & 2 \\
\hline & - & - & 2 \\
\hline \multirow[t]{2}{*}{ mauve } & - & - & 11 \\
\hline & kahvatulilla & pale purple & 2 \\
\hline \multirow[t]{3}{*}{ olive } & oliiviroheline & olive green & 8 \\
\hline & oliivikarva & olive colour(ed) & 3 \\
\hline & oliivroheline & olive green & 3 \\
\hline
\end{tabular}




\begin{tabular}{lllc}
\hline $\begin{array}{l}\text { English colour } \\
\text { term }\end{array}$ & $\begin{array}{l}\text { Translation in } \\
\text { Estonian }\end{array}$ & English gloss & $\begin{array}{c}\text { Translation } \\
\text { frequency }\end{array}$ \\
\hline peach & virsikukollane & peach yellow & 4 \\
& virsikukarva & peach colour(ed) & 3 \\
& virsikuroosa & peach pink & 3 \\
\hline pink & roosa & pink & 19 \\
& tumeroosa & dark pink & 1 \\
\hline plum & ploomililla & plum purple & 9 \\
& ploomikarva & plum colour(ed) & 4 \\
& tumelilla & dark purple & 3 \\
& - & - & 3 \\
\hline rose & roosa & pink & 9 \\
& roosipunane & rose red & 3 \\
& - & - & 2 \\
\hline salmon & lõheroosa & salmon pink & 13 \\
& löhepunane & salmon red & 2 \\
& roosa & pink & 2 \\
\hline turquoise & türkiissinine & turquoise blue & 12 \\
& türkiis & turquoise & 5 \\
\hline violet & violetne & purple & 12 \\
& lilla & purple & 7 \\
\hline
\end{tabular}

Kokkuvõte. Mari Uusküla: Empiiriline lähenemine värvinimede tõlkimisele inglise-eesti suunal. Värvinimede tõlkimist võiks pidada keeleteaduse ja tõlketeaduse siirdealaks, kuna tõlketeadus tegeleb põhiliselt suuremate üksuste uurimisega kui selleks on sõnad, kognitiivne semantika aga huvitub ka üksiksõnadest. Teemat võib pidada aktuaalseks ja uudseks, sest värvinimede tõlkimist on süstemaatiliselt uuritud vähe sellele vaatamata, et huvi värvinimede vastu eri maailma keeltes on jätkuvalt suur. Artikkel kirjeldab, kuidas kakskümmend vabatahtlikku, kelle hulgas leidus nii tõlkijaid kui ka mittetõlkijaid (s.t. inimesi, kes oma igapäevaelus ega -töös tõlkimisega ei tegele), tõlkisid inglise keelest eesti keelde kakskümmend objektist tuletatud värvinime (nt lemon, chocolate ja rose). Värvinimede tõlkimisel kerkis esile neli põhilist tõlkestrateegiat: otsetõlge, abstraheerimine või hüponüümia kasutamine, informatsiooni muutmine või väljajätt ning kirjeldav tõlge. Lisaks näitab läbiviidud uurimus, et tõlkekogemusega ja tõlkeharidust omavatel inimestel on tõlkimisel selge eelis, isegi kui tõlgitavateks üksusteks on üksiksõnad.

Märksõnad: semantika, tõlkimine, kognitiivne keeleteadus, kultuurispetsiifilised sõnad, objektipõhised värvinimed, kultuurilised märksõnad 